\title{
EFIKASI DIRI DALAM PENGAMBILAN KEPUTUSAN KARIER DAN PARENTAL CAREER-RELATED BEHAVIORS: BERPERANKAH PADA KOMITMEN TERHADAP PILIHAN KARIER REMAJA?
}

\author{
Meilita Jamilah Samosir \\ meilitajamilahs@gmail.com \\ Universitas Indonesia
}

\author{
Puji Lestari Suharso \\ puji.prianto@gmail.com \\ Universitas Indonesia
}

\begin{abstract}
This study examined the role of parental career-related behaviors towards commitment to career choice through career decision making self-efficacy among adolescents. There are 315 high school students who participated in this study origin from school in South Jakarta. Commitment to career choice was measured using commitment to career choice scale (CCCS), career decision making self-efficacy was measured using career decision self-efficacy short form (CDSE-SF), parental careerrelated behaviors was measured using parental career-related behaviors (PCB). The result found that there are significant effects of parental career-related behaviors support $(B=-0,0212, p<0,001)$, interference $(B=0,001, p<0,001)$, and lack of engagement $(B=0,138, p<0,01)$ towards vocational exploration and commitment $(V E C)$ through career decision making self-efficacy. There are also significant effects of parental career-related behaviors support $(B=-0,220, p<0,001)$, interference $(B=0,139, p<0,001)$, and lack of engagement $(B=0,073, p<0,01)$ towards tendency to foreclose (TTF) through career decision making self-efficacy. Based on the results, adolescents need support from parents on their career development. The results are discussed further in relation to theory and previous research.
\end{abstract}

Keywords: Career decision making self-efficacy, commitment to career choice, parental career-related behaviors, adolescent

\begin{abstract}
Abstrak
Penelitian ini bertujuan untuk menguji pengaruh parental career-related behaviors pada komitmen terhadap pilihan karier remaja dengan efikasi diri dalam pengambilan keputusan karier sebagai variabel mediator. Partisipan penelitian adalah siswa-siswi SMA di Jakarta Selatan $(\mathrm{N}=315)$. Komitmen terhadap pilihan karier diukur dengan Commitment to Career Choice Scale (CCCS), efikasi diri dalam pengambilan keputusan karier dengan Career Decision Self-Efficacy Short Form (CDSE-SF), serta persepsi anak terhadap perilaku orang tua terkait karier dengan Parental Career-Related Behaviors (PCB). Hasil penelitian menunjukkan bahwa parental career-related behaviors yang mendukung $(B=-0,0212, p<0,001)$, mengganggu $(B=0,001$, $p<0,001)$, dan kurang terlibat $(B=0,138, p<0,01)$ berpengaruh signifikan pada komitmen terhadap pilihan karier remaja dimensi vocational
\end{abstract}


exploration and commitment (VEC) melalui efikasi diri dalam pengambilan keputusan karier. Parental career-related behaviors yang mendukung $(B=-$ $0,220, p<0,001)$, mengganggu $(B=0,139, p<0,001)$, dan kurang terlibat $(B=0,073, p<0,01)$ juga berpengaruh signifikan pada komitmen terhadap pilihan karier remaja dimensi tendency to foreclose (TTF) melalui efikasi diri dalam pengambilan keputusan karier. Berdasarkan hasil yang didapat, tampaknya dukungan orang tua tetap diperlukan pada remaja dalam perkembangan kariernya. Hasil penelitian akan didiskusikan lebih lanjut dalam hubungannya dengan teori dan penelitian sebelumnya.

Kata kunci: efikasi diri dalam pengambilan keputusan karier, komitmen terhadap pilihan karier, parental career-related behaviors; remaja.

\section{PENDAHULUAN}

Remaja berada dalam tahap eksplorasi pada perkembangan kariernya (Super, 1957, dalam Sharf, 2010). Pada tahap eksplorasi karier, remaja melakukan usaha untuk mendapatkan lebih banyak informasi mengenai potensi, minat, berbagai peluang karier yang tersedia hingga akhirnya mampu mengambil suatu keputusan karier. Tidak hanya mengambil keputusan karier, berkomitmen terhadap pilihan karier yang telah diambil juga perlu dilakukan karena merupakan salah satu tugas perkembangan utama yang perlu diselesaikan oleh remaja (Super, 1957; Harren, 1979, dalam Caldera, Robitschek, Frame, \& Pannell, 2003). Komitmen terhadap pilihan karier adalah kepastian dan kepercayaan diri terhadap pilihan karier individu, pandangan positif mengenai masa depan karier, serta kesadaran akan rintangan yang mungkin ada (Blustein, Ellis, dan Devenis, 1989). Komitmen terhadap pilihan karier yang tinggi dapat diraih ketika remaja mampu mengenali diri dan lingkungannya, lalu pengetahuan ini digunakan untuk menghadapi berbagai rintangan yang muncul dalam perjalanan mencapai tujuan kariernya (Scott \& Church, 2011).

Berbagai penelitian telah membuktikan pentingnya komitmen terhadap pilihan karier remaja. Komitmen terhadap pilihan karier merupakan hal penting sebab berkaitan dengan berbagai aspek psikologis. Komitmen terhadap pilihan karier yang tinggi akan membuat remaja lebih termotivasi dalam belajar dan lebih berusaha untuk meraih target-target sehingga pada akhirnya akan berpengaruh positif pada prestasi akademik mereka (Lopez, 1994; Cheng \& Ho, 2001; Demirtas, 2010). Remaja dengan komitmen karier tinggi tidak akan terlalu merasakan hambatan dalam mencapai karier yang diinginkan dan akan berusaha lebih keras untuk mencapai target-target yang ditetapkan bahkan ketika mereka menghadapi berbagai rintangan (Ladany, Meloncoff, Constantine \& Love, 1997). Komitmen terhadap pilihan karier juga berhubungan dengan self esteem, 
kemampuan untuk tetap menjalankan berbagai tugas di bawah tekanan, takut untuk berkomitmen, career indecision, dan kecemasan (Betz \& Luzzo, 1996).

Fenomena di atas menunjukkan rendahnya komitmen terhadap pilihan karier remaja yang disebabkan belum cukupnya eksplorasi mengenai minat, kemampuan, serta berbagai pilihan jurusan kuliah dan pekerjaan yang tersedia sehingga mereka belum mampu atau tidak yakin dalam mengambil suatu keputusan karier. Rendahnya komitmen terhadap pilihan karier remaja khususnya pada jurusan kuliah yang telah dipilih dapat menimbulkan dampak negatif seperti perilaku berganti jurusan kuliah, tidak lulus tepat waktu, dan drop out. Hal ini tentu saja dapat menyebabkan kerugian dalam segi waktu, finansial, dan memberi dampak psikologis yang buruk pada remaja (Erikson, 1968; Hall, 1976; Solomon, Bishop, \& Blesser, 1986; Colarelli \& Bishop, 1990, dalam Demirtas, 2010; Kappler, 2015). Oleh karena itu, sangat penting bagi remaja untuk melakukan eksplorasi karier secara cermat agar mampu mengambil sebuah keputusan karier yang sesuai dengan potensi kemampuan, minat, dan peluang karier yang tersedia.

Eksplorasi karier merupakan salah satu dari dua dimensi komitmen terhadap pilihan karier, yaitu vocational exploration and commitment (VEC) dan tendency to foreclose (TTF). Vocational exploration and commitment (VEC) adalah keterbukaan individu untuk mengeksplorasi berbagai pilihan karier sebelum berkomitmen terhadap pilihan tertentu (Blustein, dkk., 1989). Konstruk vocational exploration and commitment dirancang untuk menilai perkembangan individu dalam mencapai komitmen terhadap pilihan kariernya yang berawal dari tahap tidak memiliki komitmen (uncommitted phase) sampai dengan tahap memiliki tingkat komitmen yang tinggi (highly committed phase).

Dimensi kedua dari komitmen terhadap pilihan karier adalah tendency to foreclose (TTF), yaitu keinginan untuk berkomitmen terhadap pilihan karier secepat mungkin tanpa sebuah periode eksplorasi yang cermat dan berusaha untuk bertahan pada pilihan tersebut meskipun berhadapan dengan hal-hal yang terbukti tidak mendukung (Blustein, dkk., 1989). Konstruk tendency to foreclose dirancang untuk melihat bagaimana individu berkomitmen terhadap pilihan kariernya. Pada proses berkomitmen terhadap pilihan karier, individu akan mengalami berbagai reaksi personal dan merespon dengan cara yang berbeda-beda. Sebagian individu dapat dengan leluasa bertoleransi terhadap ambiguitas dan keterbukaan dalam proses berkomitmen, sementara sebagian lainnya berusaha untuk menutup pilihan kariernya (Hilton, 1962; Jordan, 1974; Gordon, 1981; Blustein \& Strohmer, 1987, dalam Blustein, Ellis, \& Devenis, 1989).

Efikasi diri dalam pengambilan keputusan karier merupakan faktor yang konsisten memiliki hubungan dengan VEC dan TTF (Ellis, dkk., 1999; Chung, 2002; Wang, 2004; Wang, dkk., 2006; Jin, dkk., 2009). Taylor dan Betz (1983) mendefinisikan efikasi diri dalam pengambilan keputusan karier 
sebagai keyakinan individu atas kemampuan dirinya untuk menyelesaikan tugas terkait pengambilan keputusan karier. Remaja dengan efikasi diri dalam pengambilan keputusan yang baik akan memiliki VEC yang tinggi dan TTF yang rendah (Blustein, 1989; Ellis, dkk., 1999; Chung, 2002; Wang, 2004; Wang, dkk., 2006).

Peningkatan VEC dan penurunan TTF disebabkan oleh meningkatnya motivasi remaja untuk melakukan eksplorasi karier yang lebih luas ketika memiliki keyakinan tinggi bahwa ia mampu menyelesaikan berbagai tugas terkait pengambilan keputusan karier. Luasnya eksplorasi karier yang dilakukan akan menyebabkan remaja memiliki kecenderungan yang rendah untuk secepatnya berkomitmen terhadap satu pilihan karier. Remaja akan lebih cermat dalam mempertimbangkan berbagai pilihan karier yang sesuai dengan potensi kemampuan serta minat yang dimiliki.

Jika dilihat dari sumber efikasi diri (Bandura, 1977), orang tua merupakan sumber verbal persuasion efikasi diri yang penting bagi remaja. Verbal persuasion berupa dukungan dan dorongan dari orang tua akan berkontribusi pada persepsi remaja mengenai kemampuan menyelesaikan tugas terkait karier yang dimilikinya. Dukungan tersebut akan membuat remaja lebih percaya diri dan yakin untuk menyelesaikan tugas-tugas pengambilan keputusan karier sehingga mendorong remaja untuk lebih aktif mengeksplorasi karier (VEC tinggi) dan tidak terburu-buru dalam berkomitmen terhadap satu pilihan karier (TTF rendah).

Pentingnya peran orang tua dalam meningkatkan efikasi diri dalam pengambilan keputusan karier juga tergambar dari hasil studi awal yang peneliti lakukan terhadap 104 remaja. Sebanyak $70 \%$ remaja menyatakan bahwa orang tua yang bersikap mendukung dan menjadi tempat berdiskusi, merupakan faktor penting yang membantu mereka yakin dalam mengambil keputusan jurusan kuliah. Melihat hasil tersebut, peneliti tertarik untuk menggali lebih dalam mengenai peran orang tua dalam karier remaja.

Peran orang tua dalam karier remaja dapat dilihat melalui sikap orang tua terhadap perkembangan karier anaknya yang diistilahkan dengan parental career-related behaviors (Dietrich \& Kracke, 2009). Terdapat tiga jenis parental career-related behaviors, yaitu: mendukung (support), mengganggu (interference), dan kurang terlibat (lack of engagement). Ketiganya merupakan hasil rangkuman Dietrich dan Kracke (2009) dari berbagai penelitian (Altman, 1997; Schultheiss, dkk., 2001; Mortimer, dkk. 2002; Oeschsle, dkk., 2002; Kracke \& Noack, 2005, dalam Dietrich dan Kracke, 2009).

Parental career-related behaviors mendukung ditunjukkan orang tua misalnya melalui pemberian masukan ketika remaja membutuhkan tempat untuk berdiskusi mengenai pilihan karier yang akan mereka ambil, pemberian informasi terkait kesempatan magang, dll. Dukungan tersebut akan meningkatkan keyakinan remaja mengenai kemampuannya dalam menyelesaikan berbagai tugas pengambilan keputusan karier yang selanjutnya akan meningkatkan motivasi mereka untuk terlibat aktif dalam 
kegiatan eksplorasi karier. Keterlibatan remaja secara aktif dalam kegiatan eksplorasi karier menunjukkan tingkat VEC yang tinggi. Ketika remaja telah mendapatkan berbagai informasi mengenai diri dan lingkungannya melalui eksplorasi karier, ia akan lebih cermat dalam mengambil suatu keputusan karier dan tidak terburu-buru berkomitmen terhadap satu pilihan karier yang menunjukkan tingkat TTF yang rendah.

Parental career-related behaviors mengganggu ditunjukkan orang tua misalnya dengan terlalu turut ikut campur dalam persiapan karier remaja, mengontrol perkembangan dan aspirasi karier remaja dengan memaksakan pendapat mereka mengenai jurusan kuliah atau pekerjaan yang baik kepada remaja. Hal ini dapat menyebabkan penurunan tingkat keyakinan remaja akan kemampuannya dalam menyelesaikan tugas terkait pengambilan keputusan karier dan akhirnya menjadi pasif dalam melakukan eksplorasi karier. Kepasifan remaja dalam eksplorasi karier menunjukkan rendahnya tingkat VEC yang dapat berdampak pada meningkatnya TTF remaja sehingga mereka cenderung untuk segera mengikuti pilihan karier orang tuanya tanpa mempertimbangkan secara cermat minat dan kemampuan yang dimiliki.

Parental career-related behaviors kurang terlibat ditunjukkan orang tua yang tidak berpartisipasi dalam perkembangan karier remaja. Tidak terlibatnya orang tua dapat disebabkan berbagai hal misalnya merasa karier anaknya tidak terlalu penting, terlalu sibuk dengan urusan pemenuhan kebutuhan hidup, atau tidak mampu menyediakan informasi terkait karier bagi anaknya. Orang tua yang menunjukkan perilaku kurang terlibat akan mengurangi tingkat keyakinan remaja mengenai kemampuannya dalam menyelesaikan berbagai tugas terkait pengambilan keputusan karier yang selanjutnya akan berakibat pada kurang stabilnya arah karier remaja. Kurang stabilnya arah karier remaja disebabkan oleh kurangnya rasa percaya diri dalam melakukan eksplorasi karier dan timbulnya perasaan tidak memiliki significant other yang dapat membantunya ketika menghadapi kesulitan dalam proses eksplorasi karier. Hal ini dapat menyebabkan remaja menjadi kurang terlibat dalam kegiatan eksplorasi karier (tingkat VEC rendah) dan cenderung secepatnya memilih untuk berkomitmen terhadap satu pilihan (tingkat TTF tinggi).

Berdasarkan uraian yang telah dikemukakan di atas, dapat terlihat bahwa parental career-related behaviors memengaruhi efikasi diri dalam pengambilan keputusan karier remaja yang selanjutnya akan berpengaruh pada tingkat VEC dan TTF yang mereka miliki. Hal ini menunjukkan bahwa efikasi diri dalam pengambilan keputusan karier dapat berperan sebagai mediator pada hubungan parental career-related behaviors dan komitmen terhadap pilihan karier dimensi VEC dan TTF.

Beberapa penelitian telah membuktikan bahwa efikasi diri dalam pengambilan keputusan karier memberi efek mediasi antara komitmen terhadap karier dengan berbagai aspek psikologis, seperti kepribadian 
(Wang, 2004; Wang, dkk., 2006; Jin, dkk., 2009) dan kelekatan pada orang tua (Lee \& Kim, 2015). Oleh karena parental career-related behaviors berhubungan dengan efikasi diri dalam pengambilan keputusan karier dan adanya bukti bahwa efikasi diri dalam pengambilan keputusan karier merupakan mediator antara suatu variabel dengan komitmen terhadap pilihan karier, maka peneliti menduga bahwa parental career-related behavior dapat berhubungan dengan komitmen terhadap pilihan karier dimensi VEC dan TTF melalui efikasi diri dalam pengambilan keputusan karier. Penelitian ini akan membuktikannya dengan melibatkan siswa SMA dengan mengajukan hipotesis penelitian sebagai berikut:

$\mathrm{Ho}_{1}$ : Tidak terdapat pengaruh signifikan parental career-related behaviors yang mendukung pada komitmen terhadap pilihan karier dimensi vocational exploration and commitment melalui efikasi diri dalam pengambilan keputusan karier remaja.

$\mathrm{Ho}_{2}$ : Tidak terdapat pengaruh signifikan parental career-related behaviors yang mengganggu pada komitmen terhadap pilihan karier dimensi vocational exploration and commitment melalui efikasi diri dalam pengambilan keputusan karier remaja.

$\mathrm{Ho}_{3}$ : Tidak terdapat pengaruh signifikan parental career-related behaviors yang kurang terlibat pada komitmen terhadap pilihan karier dimensi vocational exploration and commitment melalui efikasi diri dalam pengambilan keputusan karier remaja.

$\mathrm{Ho}_{4}$ : Tidak terdapat pengaruh signifikan parental career-related behaviors yang mendukung pada komitmen terhadap pilihan karier dimensi tendency to foreclosed melalui efikasi diri dalam pengambilan keputusan karier remaja. $\mathrm{Ho}_{5}$ : Tidak terdapat pengaruh signifikan parental career-related behaviors yang mengganggu pada komitmen terhadap pilihan karier dimensi tendency to foreclosed melalui efikasi diri dalam pengambilan keputusan karier remaja. $\mathrm{Ho}_{6}$ : Tidak terdapat pengaruh signifikan parental career-related behaviors yang kurang terlibat pada komitmen terhadap pilihan karier dimensi tendency to foreclosed melalui efikasi diri dalam pengambilan keputusan karier remaja.

\section{METODE PENELITIAN}

\section{Partisipan dan Prosedur}

Partisipan penelitian ini adalah 315 siswa SMA di Jakarta Selatan berusia 14 hingga 18 tahun yang diperoleh dengan teknik pengambilan sampel convenience sampling. Pengambilan data dilakukan dengan memberikan kuesioner penelitian kepada siswa saat pelajaran Bimbingan Konseling setelah mendapatkan izin dari pihak sekolah. 


\section{Pengukuran}

Variabel komitmen terhadap pilihan karier diukur dengan menggunakan Commitment to Career Choices Scale (CCCS) yang disusun oleh Blustein, Ellis, dan Devenis (1989) yang telah diadaptasi oleh peneliti ke dalam Bahasa Indonesia. Alat ukur ini terdiri atas 28 item dengan menggunakan skala likert dengan rentang 1 (sangat tidak sesuai) hingga 6 (sangat sesuai). Alat ukur ini memiliki dua subskala yaitu Vocational Exploration and Commitment Subscale (VECS) yang terdiri atas 19 item, dan Tendency to Foreclose Subscale (TTFS) yang terdiri atas 9 item. Blustein, Ellis, dan Devenis (1989) menyatakan bahwa vocational exploration and commitment dan tendency to foreclose merupakan dua dimensi yang discrete dan independent pada proses berkomitmen terhadap pilihan karier. Oleh karena itu, akan diperoleh skor total yang terpisah antara VECS dan TTFS.

Variabel parental career-related behaviors diukur dengan menggunakan Parental Career-Related Behaviors (PCB) yang dikembangkan oleh Dietrich dan Kracke (2009) dan diadaptasi ke dalam Bahasa Indonesia oleh Maulidiyah (2017). Alat ukur ini terdiri atas tiga skala, yakni dukungan, mengganggu, dan kurang keterlibatan yang memiliki skor total terpisah. Setiap skala diukur melalui lima item sehingga seluruh item berjumlah 15 item. Alat ukur PCB ini menggunakan skala likert dengan rentang 1 (sangat tidak sesuai) hingga 6 (sangat sesuai) pada pilihan respon jawabannya.

Variabel efikasi diri pengambilan keputusan karier diukur dengan menggunakan Career Decision Self-Efficacy Short Form (CDSE-SF) yang dikembangkan oleh Sawitri, Creed, dan Zimmer-Gembeck (2012) berdasarkan Career Decision Making Self-Efficacy (CDMSE) yang disusun oleh Taylor dan Betz (1983). Alat ukur CDSE-SF ini terdiri atas lima skala pengukuran yaitu penilaian diri, informasi pekerjaan, pemilihan tujuan, perencanaan karier, dan penyelesaian masalah. Masing-masing skala terdiri atas lima item sehingga total item berjumlah 25 item. Respon jawaban partisipan pada alat ukur CDSE-SF diukur menggunakan skala likert dengan rentang 1 (sangat tidak yakin) hingga 6 (sangat yakin).

Uji reliabilitas untuk ketiga alat ukur yang digunakan menunjukkan bahwa ketiganya memiliki koefisien reliabilitas yang baik digunakan pada penelitian, yaitu: CCCS subksala Vocational Exploration and Commitment Subscale (VECS) sebesar 0,937, dan subskala Tendency to Foreclose Subscale (TTFS) memiliki koefisien reliabilitas sebesar 0,753. Sementara itu, diperoleh koefisien sebesar 0,744 untuk PCB dimensi dukungan sebesar 0,744 , dimensi mengganggu sebesar 0,745 , dimensi kurang terlibat nilai reliabilitas sebesar 0,804. Sementara itu CDSE-SF memiliki koefisien reliabilitas sebesar 0,887 . Setelah uji coba dilakukan, tidak ada item yang dihapus namun terdapat beberapa item yang mengalami perubahan kalimat agar lebih mudah dipahami. 


\section{Analisis Data}

Hubungan antara ketiga variabel dianalisis dengan menggunakan multiple regression dengan bantuan program SPSS. Lebih lanjut, analisis mediasi menggunakan path analysis SPSS PROCESS yang dikembangkan oleh Hayes (2013).

\section{HASIL PENELITIAN}

\section{Karakteristik Partisipan}

Partisipan yang terlibat pada penelitian ini lebih banyak berjenis kelamin perempuan yaitu sebanyak 59,7\% dari total 315 partisipan. Meskipun demikian, selisih jumlah partisipan perempuan dan laki-laki tidak terlalu banyak. Dalam segi usia, rentang usia partisipan berkisar antara 14 tahun hingga 18 tahun. Partisipan berusia 16 tahun merupakan yang paling banyak terlibat dalam penelitian ini yaitu sebesar $52,7 \%$.

\section{Hasil Uji Hipotesis}

Analisis regresi dilakukan untuk menguji pemenuhan tiga kondisi yang menjadi syarat adanya pengaruh mediasi (Baron \& Kenny, 1986). Kondisi pertama (c) untuk menguji bahwa parental career-related behaviors (mendukung, mengganggu, dan kurang terlibat) merupakan prediktor yang signifikan dari komitmen terhadap pilihan karier (dimensi VEC dan TTF). Kondisi kedua (a) untuk menguji bahwa parental career-related behaviors (mendukung, mengganggu, dan kurang terlibat) merupakan prediktor yang signifikan dari efikasi diri dalam pengambilan keputusan karier. Kondisi ketiga (b dan c) untuk mengetahui peran parental career-related behaviors (mendukung, mengganggu, dan kurang terlibat) dan efikasi diri dalam pengambilan keputusan karier dalam memprediksi komitmen terhadap pilihan karier (dimensi VEC dan TTF).

\section{Bagan 1}

Pengaruh Parental Career Related Behaviors terhadap Vocational Exploration and Commitment (VEC) melalui Efikasi Diri dalam Pengambilan Keputusan Karier

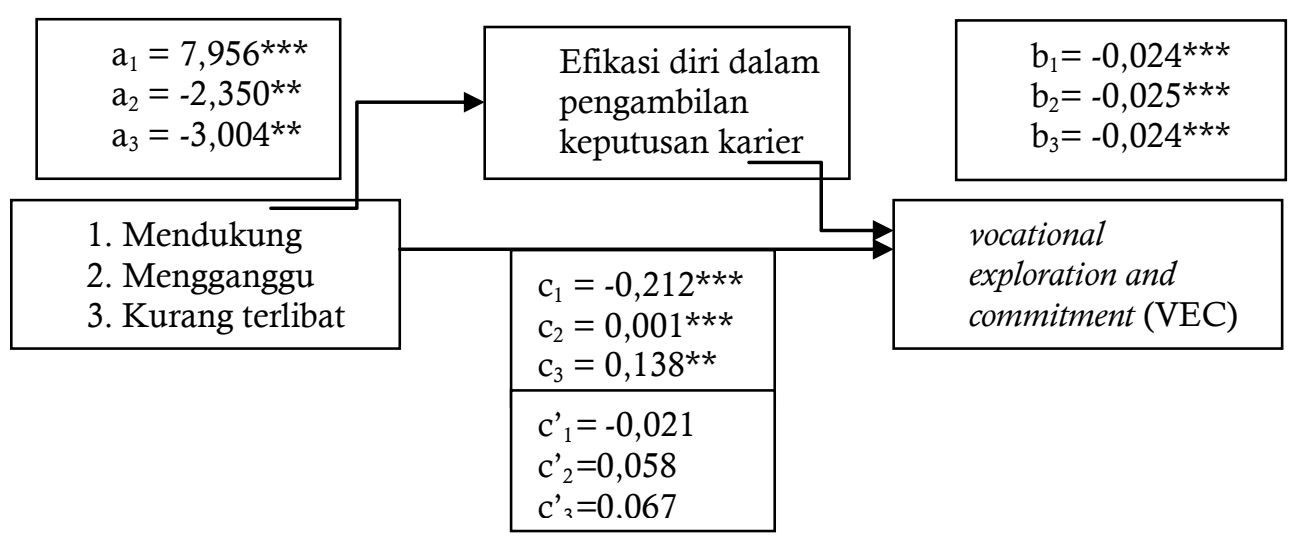

Keterangan: Signifikan bila tanda * $\mathrm{P}<0,05$, tanda ** $\mathrm{P}<0,01$, tanda *** $\mathrm{P}<0,001$ 
Bagan 1 menunjukkan bahwa parental career-related behaviors (mendukung, mengganggu, dan kurang terlibat) terbukti berpengaruh signifikan terhadap dimensi VEC dari komitmen terhadap pilihan karier melalui variabel mediator efikasi diri dalam pengambilan keputusan karier, dengan penjelasan sebagai berikut:

1. Parental career-related behaviors yang mendukung berpengaruh signifikan terhadap VEC $\left(\mathrm{c}_{1}\right)$ dengan koefisien $=-0,212, \mathrm{P}=0,000$. Parental careerrelated behaviors yang mendukung juga berpengaruh signifikan terhadap efikasi diri dalam pengambilan keputusan karier $\left(a_{1}\right)$ dengan koefisien $=7,956, \mathrm{P}=0,000$. Efikasi diri dalam pengambilan keputusan karierjuga berpengaruh signifikan terhadap VEC dengan nilai koefisien $\left(b_{1}\right)=-0,024, P=0,000$. Parental career-related behaviors yang mendukung remaja menjadi tidak signifikan pengaruhnya terhadap VEC ketika efikasi diri dalam pengambilan keputusan karier berperan sebagai mediator. Hal ini dapat dilihat dari koefisien $\left(C^{\prime}{ }_{1}\right)=-0,021, P=0,665$. Peran mediasi efikasi diri dalam pengambilan keputusan karier terbukti melalui indirect effect yang menghasilkan confidence interval $95 \%\left(\mathrm{CI}^{95}\right)$ yang nilainya berada pada rentang $=[-0,252-(-0,139)]$ dimana nilai tersebut tidak melewati angka 0 . Hasil ini menunjukkan bahwa orang tua yang menunjukkan sikap mendukung terkait karier anaknya akan meningkatkan keyakinan remaja pada kemampuannya dalam menyelesaikan tugas terkait pengambilan keputusan karier yang selanjutnya akan membuatnya semakin terbuka dalam bereksplorasi dan berkomitmen terhadap karier.

2. Parental career-related behaviors yang mengganggu berpengaruh signifikan terhadap VEC $\left(\mathrm{c}_{2}\right)$ dengan koefisien $=0,001, \mathrm{P}=0,000$. Parental careerrelated behaviors yang mengganggu juga berpengaruh signifikan terhadapefikasi diri dalam pengambilan keputusan karier $\left(a_{2}\right)$ dengan koefisien $=-2,350, \mathrm{P}=0,003$. Efikasi diri dalam pengambilan keputusan karierjuga berpengaruh signifikan terhadap VEC dengan nilai koefisien $\left(b_{2}\right)=-0,025, P=0,000$. Parental career-related behaviors yang mengganggu menjadi tidak signifikan pengaruhnya terhadap VEC ketika efikasi diri dalam pengambilan keputusan karier berperan sebagai mediator. Hal ini dapat dilihat dari nilai koefisien $\left(\mathrm{C}_{2}^{\prime}\right)=0,058, \mathrm{P}=0,069$. Peran mediasi efikasi diri dalam pengambilan keputusan karier terbukti melalui indirect effect yang menghasilkan confidence interval $95 \%\left(\mathrm{CI}^{95}\right)$ yang nilainya berada pada rentang $=[-0,108-(-0,014)]$ dimana nilai tersebut tidak melewati angka 0 . Hasil ini menunjukkan bahwa orang tua yang menunjukkan sikap mengganggu terkait karier anaknya akan menurunkan keyakinan remaja pada kemampuannya dalam menyelesaikan tugas terkait pengambilan keputusan karier yang selanjutnya akan menurunkan keterbukaan dalam bereksplorasi dan berkomitmen terhadap kariernya. 
3. Parental career-related behaviors yang kurang terlibat berpengaruh signifikan terhadap VEC $\left(\mathrm{c}_{3}\right)$ dengan koefisien $=0,138, \mathrm{P}=0,002$. Parental career-related behaviors yang kurang terlibat juga berpengaruh signifikan terhadap efikasi diri dalam pengambilan keputusan karier $\left(a_{3}\right)$ dengan koefisien $=-3,004, \mathrm{P}=0,002$. Efikasi diri dalam pengambilan keputusan karierjuga berpengaruh signifikan terhadap VEC dengan nilai koefisien $\left(b_{3}\right)=-0,024, P=0,000$. Parental career-related behaviors yang kurang terlibat menjadi tidak signifikan pengaruhnya terhadap VEC ketika efikasi diri dalam pengambilan keputusan karier berperan sebagai mediator. Hal ini dapat dilihat dari nilai koefisien $\left(C_{3}^{\prime}\right)=0,067, P=0,089$. Peran mediasi efikasi diri dalam pengambilan keputusan karier terbukti melalui indirect effect yang menghasilkan confidence interval $95 \%\left(\mathrm{CI}^{95}\right)$ yang nilainya berada pada rentang $=[0,027-0,126)]$ dimana nilai tersebut tidak melewati angka 0 . Hasil ini menunjukkan bahwa orang tua yang menunjukkan sikap kurang terlibat terkait karier anaknya akan menurunkan keyakinan remaja pada kemampuannya dalam menyelesaikan tugas terkait pengambilan keputusan karier yang selanjutnya akan menurunkan keterbukaan dalam bereksplorasi dan berkomitmen terhadap kariernya.

\section{Bagan 2}

Pengaruh Parental Career Related Behaviors terhadap Tendency to Foreclose (TTF) melalui Efikasi Diri dalam Pengambilan Keputusan Karier

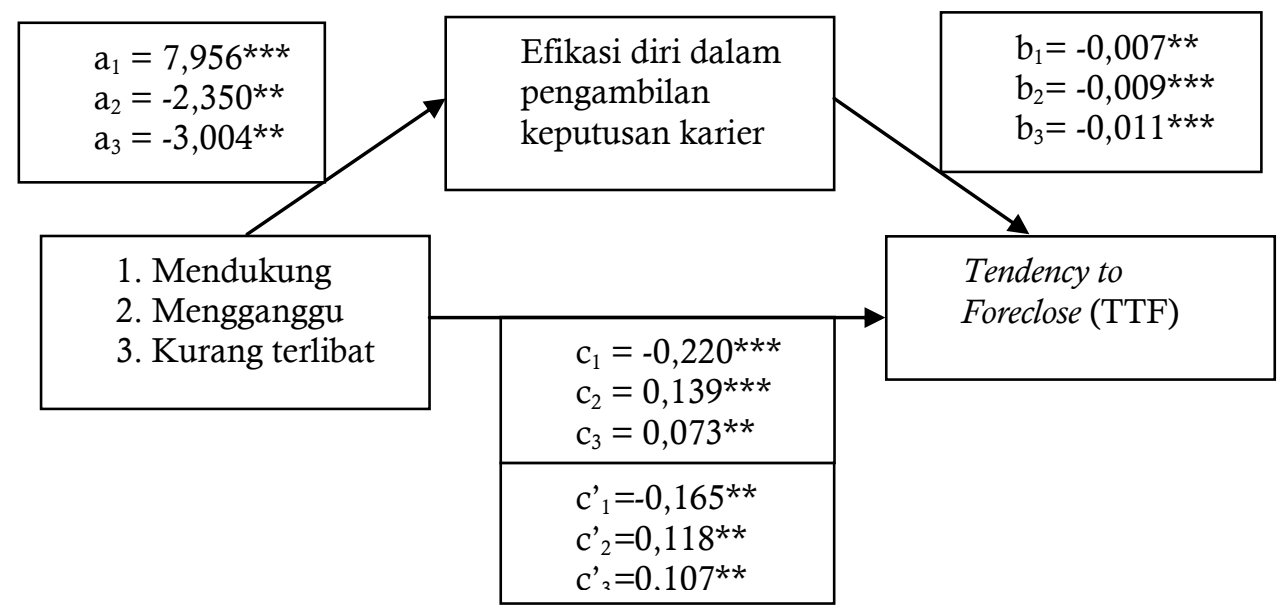

Keterangan: Signifikan bila tanda * $\mathrm{P}<0,05$, tanda ** $\mathrm{P}<0,01$, tanda $* * *$ $\mathrm{P}<0,001$

Bagan 2 menunjukkan bahwa parental career-related behaviors (mendukung, mengganggu, dan kurang terlibat) terbukti berpengaruh 
signifikan terhadap dimensi TTF dari komitmen terhadap pilihan karier melalui variabel mediator efikasi diri dalam pengambilan keputusan karier, dengan penjelasan sebagai berikut:

1. Parental career-related behaviors yang mendukung berpengaruh signifikan terhadap TTF $\left(\mathrm{c}_{1}\right)$ dengan koefisien $=-0,220, \mathrm{P}=0,000$. Parental careerrelated behaviors yang mendukung juga berpengaruh signifikan terhadapefikasi diri dalam pengambilan keputusan karier $\left(a_{1}\right)$ dengan koefisien $=7,956, \mathrm{P}=0,000$. Efikasi diri dalam pengambilan keputusan karierjuga berpengaruh signifikan terhadap TTF dengan nilai koefisien $\left(b_{1}\right)=-0,007, P=0,001$. Parental career-related behaviors yang mendukung orang tua terhadap karier remaja menjadi berkurang signifikan pengaruhnya terhadap TTF ketika efikasi diri dalam pengambilan keputusan karier berperan sebagai mediator. $\mathrm{Hal}$ ini dapat dilihat dari nilai koefisien $\left(C^{\prime}{ }_{1}\right)=-0,165, P=0,002$. Peran mediasi efikasi diri dalam pengambilan keputusan karier terbukti melalui indirect effect yang menghasilkan confidence interval $95 \%\left(\mathrm{CI}^{95}\right)$ yang nilainya berada pada rentang $=[-0,012-(-0,103)]$ dimana nilai tersebut tidak melewati angka 0 . Hasil ini menunjukkan bahwa orang tua yang menunjukkan sikap mendukung terkait karier anaknya akan meningkatkan keyakinan remaja akan kemampuannya dalam menyelesaikan tugas terkait pengambilan keputusan, yang selanjutnya akan menurunkan kecenderungan remaja untuk secepat mungkin berkomitmen terhadap satu pilihan karier tanpa eksplorasi yang cermat.

2. Parental career-related behaviors yang mengganggu berpengaruh signifikan terhadap TTF $\left(\mathrm{c}_{2}\right)$ dengan koefisien $=0,139, \mathrm{P}=0,000$. Parental careerrelated behaviors yang mengganggu juga berpengaruh signifikan terhadapefikasi diri dalam pengambilan keputusan karier $\left(\mathrm{a}_{2}\right)$ dengan koefisien $=-2,350, \mathrm{P}=0,003$. Efikasi diri dalam pengambilan keputusan karierjuga berpengaruh signifikan terhadap TTF dengan nilai koefisien $\left(b_{2}\right)=-0,025, P=0,000$. Parental career-related behaviors yang mengganggu menjadi berkurang signifikan pengaruhnya terhadap TTF ketika efikasi diri dalam pengambilan keputusan karier berperan sebagai mediator. $\mathrm{Hal}$ ini dapat dilihat dari nilai koefisien $\left(\mathrm{C}_{2}^{\prime}\right)=0,118, \mathrm{P}=0,001$. Peran mediasi efikasi diri dalam pengambilan keputusan karier terbukti melalui indirect effect yang menghasilkan confidence interval $95 \%\left(\mathrm{CI}^{95}\right)$ yang nilainya berada pada rentang $=[0,005-0,047)]$ dimana nilai tersebut tidak melewati angka 0 . Hasil ini menunjukkan bahwa orang tua yang menunjukkan sikap mengganggu terkait karier anaknya akan menurunkan keyakinan remaja akan kemampuannya dalam menyelesaikan tugas terkait pengambilan keputusan, yang selanjutnya akan meningkatkan kecenderungan remaja untuk secepat mungkin berkomitmen terhadap satu pilihan karier tanpa eksplorasi yang cermat.

3. Parental career-related behaviors yang kurang terlibat berpengaruh signifikan terhadap TTF $\left(c_{3}\right)$ dengan koefisien $=0,073, P=0,001$. Parental 
career-related behaviors yang kurang terlibat juga berpengaruh signifikan terhadapefikasi diri dalam pengambilan keputusan karier $\left(a_{3}\right)$ dengan koefisien=-3,004, $\mathrm{P}=0,002$. Efikasi diri dalam pengambilan keputusan karierjuga berpengaruh signifikan terhadap TTF dengan nilai koefisien $\left(b_{3}\right)=-0,011, P=0,000$. Parental career-related behaviors yang kurang terlibat menjadi berkurang signifikan pengaruhnya terhadap TTF ketika efikasi diri dalam pengambilan keputusan karier berperan sebagai mediator. Hal ini dapat dilihat dari nilai koefisien $\left(C^{\prime}{ }_{3}\right)=0,107, P=0,015$. Peran mediasi efikasi diri dalam pengambilan keputusan karier terbukti melalui indirect effect yang menghasilkan confidence interval $95 \%\left(\mathrm{CI}^{95}\right)$ yang nilainya berada pada rentang $=[-0,063-(-0,011)]$ dimana nilai tersebut tidak melewati angka 0 . Hasil ini menunjukkan bahwa orang tua yang menunjukkan sikap kurang terlibat pada karier anaknya akan menurunkan keyakinan remaja akan kemampuannya dalam menyelesaikan tugas terkait pengambilan keputusan, yang selanjutnya akan meningkatkan kecenderungan remaja untuk secepat mungkin berkomitmen terhadap satu pilihan karier tanpa eksplorasi yang cermat.

\section{KESIMPULAN DAN SARAN}

\section{Diskusi}

Penelitian ini bertujuan untuk menguji pengaruh parental careerrelated behaviors (mendukung, mengganggu, dan kurang terlibat) pada komitmen terhadap pilihan karier (dimensi VEC dan TTF) melalui efikasi diri dalam pengambilan keputusan karier. Hasil penelitian membuktikan bahwa seluruh hipotesis nol yang diajukan pada penelitian ini ditolak. Hal ini menunjukkan bahwa:

A. Terdapat pengaruh signifikan parental career-related behaviors yang mendukung pada komitmen terhadap pilihan karier dimensi vocational exploration and commitment melalui efikasi diri dalam pengambilan keputusan karier remaja.

B. Terdapat pengaruh signifikan parental career-related behaviors yang mengganggu pada komitmen terhadap pilihan karier dimensi vocational exploration and commitment melalui efikasi diri dalam pengambilan keputusan karier remaja.

C. Terdapat pengaruh signifikan parental career-related behaviors yang kurang terlibat pada komitmen terhadap pilihan karier dimensi vocational exploration and commitment melalui efikasi diri dalam pengambilan keputusan karier remaja.

D. Terdapat pengaruh signifikan parental career-related behaviors yang mendukung pada komitmen terhadap pilihan karier dimensi tendency to foreclose melalui efikasi diri dalam pengambilan keputusan karier remaja. 
E. Terdapat pengaruh signifikan parental career-related behaviors yang mengganggu pada komitmen terhadap pilihan karier dimensi tendency to foreclose melalui efikasi diri dalam pengambilan keputusan karier remaja.

F. Terdapat pengaruh signifikan parental career-related behaviors yang kurang terlibat pada komitmen terhadap pilihan karier dimensi tendency to foreclose melalui efikasi diri dalam pengambilan keputusan karier remaja.

Penelitian ini membuktikan adanya pengaruh signifikan parental career-related behaviors (mendukung, mengganggu, dan kurang terlibat) pada komitmen terhadap pilihan karier (dimensi VEC dan TTF) dengan efikasi diri dalam pengambilan keputusan karier yang berperan sebagai mediator. Hasil ini sejalan dengan penelitian yang dilakukan oleh Dietrich dan Kracke (2009) serta Guan, dkk. (2016).

Parental career-related behaviors mendukung dapat ditunjukkan oleh orang tua dengan mendorong remaja untuk mengeksplorasi berbagai pilihan jurusan kuliah dan pekerjaan yang tersedia, membantu mengenali potensi kemampuan dan minat yang remaja miliki, serta memberikan saran saat remaja kebingungan dalam menentukan pilihan jurusan kuliah yang akan diambil setelah tamat SMA. Orang tua juga dapat memberikan dukungan dengan menyediakan informasi terkait program magang dan beasiswa yang tersedia bagi mahasiswa di berbagai jurusan kuliah. Bentuk dukungan yang diberikan orang tua dapat berupa instrumental support, misalnya dukungan finansial atau saran terkait pendidikan dan juga socio-emotional support, misalnya memberikan kesempatan untuk belajar dan mengeksplorasi kecocokan antara dirinya dan berbagai pekerjaan. Socio-emotional support yang diberikan orang tua dapat mengatasi stress yang dapat timbul selama proses berkomitmen terhadap karier (Hargrove, Creagh, \& Burgess, 2002; Guan, dkk., 2016).

Berbagai bentuk dukungan di atas dapat meningkatkan keyakinan remaja akan kemampuannya dalam menyelesaikan berbagai tugas terkait pengambilan keputusan karier yang selanjutnya akan membantu remaja mendapatkan insight terkait tujuan kariernyadan lebih termotivasi mengeksplorasi karier secara luas. Keterbukaan remaja dalam melakukan eksplorasi berbagai pilihan karier menunjukkan bahwa mereka memiliki VEC yang tinggi. Ketika remaja memiliki VEC yang tinggi, mereka akan mampu mengatasi rasa ketidaknyamanan selama proses pemilihan karier dan lebih terbuka terhadap berbagai pengalaman karier sebelum memutuskan untuk berkomitmen terhadap satu pilihan karier. Hal ini menunjukkan bahwa remaja memiliki TTF yang rendah sehingga mereka tidak memiliki kecenderungan untuk secepatnya berkomitmen terhadap satu pilihan karier tanpa eksplorasi karier yang cermat. 
Parental career-related behaviors mengganggu ditunjukkan orang tua dengan mengontrol persiapan dan aspirasi karier remaja. Orang tua berusaha memaksakan sudut pandang mereka mengenai karier yang baik bagi remaja, misalnya ketika orang tua berprofesi sebagai pengacara maka anaknya dipaksa untuk mengambil jurusan hukum pada saat kuliah agar nantinya dapat menjadi pengacara seperti orang tuanya meskipun minat dan kemampuan yang dimiliki anaknya tidak sesuai dengan jurusan tersebut. Remaja tidak diberikan kesempatan untuk melakukan eksplorasi terhadap minat, kemampuan serta berbagai pilihan karier yang tersedia di lingkungannya.

Parental career-related behaviors mengganggu dapat mengurangi rasa percaya diri dan keyakinan remaja akan kemampuannya dalam menyelesaikan tugas-tugas terkait pengambilan keputusan karier yang selanjutnya menyebabkan rendahnya kemandirian dan motivasi intrinsik remaja dalam melakukan eksplorasi karier. Hal ini mengakibatkan remaja menjadi pasif dalam aktivitas eksplorasi karier. Kepasifan dalam eksplorasi karier menunjukkan tingkat VEC yang rendah pada remaja. Remaja juga cenderung akan memiliki tingkat TTF yang tinggi karena mereka akan secepatnya berkomitmen terhadap pilihan karier yang dipaksakan oleh orang tuanya tanpa melakukan eksplorasi terhadap berbagai pilihan lain yang tersedia dan sesuai dengan minatnya.

Parental career-related behaviors kurang terlibat ditunjukkan orang tua yang tidak mampu atau ragu-ragu untuk terlibat pada perkembangan karier anaknya. Hal ini dapat disebabkan oleh kesibukan dalam memenuhi kebutuhan hidup keluarga, pandangan bahwa persiapan karier anaknya bukanlah hal yang penting, atau orang tua tidak memiliki kemampuan dalam membantu remaja mengatasi berbagai tantangan pada perkembangan karier mereka. Kurang terlibatnya orang tua dalam karier anaknya juga mengakibatkan tingginya tingkat kesulitan remaja dalam menyelesaikan masalah-masalah dalam eksplorasi karier sebab mereka merasa tidak memiliki significant other yang dapat membantu dan mendukungnya. Remaja merasa tidak memiliki tempat untuk berdiskusi terkait minat, kemampuan, serta berbagai pilihan jurusan kuliah dan pekerjaan yang tersedia.

Kurangnya keterlibatan orang tua terkait karier anaknya dapat menyebabkan rendahnya keyakinan remaja akan kemampuannya dalam menyelesaikan berbagai tugas terkait pengambilan keputusan karier. Hal ini selanjutnya akan berdampak pada rendahnya VEC yang dimiliki sebab mereka kurang termotivasi dalam melakukan eksplorasi karier. Kurangnya informasi mengenai diri dan lingkungannya dapat menyebabkan tingginya tingkat TTF pada remaja karena mereka cenderung untuk secepatnya berkomitmen terhadap satu pilihan karier berdasarkan informasi yang terbatas. Kecenderungan untuk secepatnya berkomitmen terhadap satu pilihan karier dilakukan untuk menghilangkan kecemasan dan 
ketidaknyamanan yang dapat timbul selama proses pemilihan karier berlangsung.

Pengaruh yang signifikan parental career-related behaviors terhadap efikasi diri dalam pengambilan keputusan karier dapat dijelaskan melalui sumber efikasi diri yang diungkapkan oleh Bandura (1977). Parental careerrelated behaviors merupakan salah satu sumber verbal persuasion efikasi diri dalam pengambilan keputusan remaja yang diberikan dalam bentuk dukungan dan dorongan untuk melakukan aktivitas eksplorasi karier sehingga meningkatkan VEC yang dimiliki oleh remaja. Selain menjadi sumber verbal persuasion, orang tua juga menjadi sumber vicarious learning/social modeling bagi efikasi diri dalam pengambilan keputusan remaja (Lent, Brown, \& Hackett, 2000). Orang tua merupakan salah satu faktor lingkungan penting yang memengaruhi kesuksesan dalam memilih karier karena orang tua dapat membentuk pengalaman belajar (learning experiences) yang akan menstimulasi remaja untuk mengembangkan keyakinan bahwa dirinya mampu melakukan berbagai tugas keputusan karier dan membentuk harapan akan hasil yang positif (positive outcome expectation).

Orang tua menjadi role model yang penting bagi remaja, terlebih lagi pada budaya kolektif seperti yang dimiliki masyarakat Indonesia dimana evaluasi dibuat oleh anggota didalam kelompok terutama yang lebih berkuasa misalnya orang tua (Sawitri, Creed, \& Zimmer-Gembect, 2012). Remaja yang dibesarkan pada budaya kolektif seperti di Indonesia sangat menghormati pendapat orang tuanya sehingga keputusan karier yang sesuai (congruence) dengan harapan orang tua akan menjadi pendorong utama dalam peningkatan efikasi diri dalam pengambilan keputusan kariernya.

Pengaruh yang signifikan efikasi diri dalam pengambilan keputusan karier dan pada komitmen terhadap pilihan karier juga dapat dijelaskan melalui dimensi efikasi diri dalam pengambilan keputusan karier. Agar komitmen terhadap pilihan karier remaja meningkat dari uncommitted phase menuju highly committed phase, remaja perlu melakukan serangkaian tugas meliputi: self appraisal, mengumpulkan informasi terkait karier, menetapkan tujuan, dan membuat rencana yang merupakan dimensi dari efikasi diri dalam pengambilan keputusan karier (Crite, 1978, dalam Blustein, 1989; Taylor \& Betz, 1983; Betz \& Taylor, 2006).

Melalui self appraisal remaja dapat mengukur dengan baik mengenai minat dan kemampuan yang ia miliki. Remaja akan menyesuaikan hasil self appraisal tersebut dengan jurusan kuliah dan bidang pekerjaan yang diperoleh dari proses pengumpulan informasi terkait karier sehingga mampu menetapkan tujuan dan membuat rencana karier yang baik. Ketika remaja memiliki rencana karier yang baik dan sesuai dengan minat serta kemampuannya, maka remaja akan lebih mampu mengatasi kesulitan serta tantangan yang mungkin timbul selama proses pencapaian tujuan karier. Remaja yang mampu mengatasi berbagai kesulitan dalam pencapaian 
kariernya menunjukkan bahwa ia memiliki tingkat VEC yang tinggi dan tingkat TTF yang rendah.

Pada pelaksanaan penelitian ini, peneliti memiliki beberapa limitasi. Salah satunya adalah tidak lengkapnya pengisian kuesioner yang dilakukan oleh beberapa partisipan. Hal ini mungkin disebabkan oleh perbedaan aktivitas yang dijalankan sebelum pengisian kuesioner sehingga berpengaruh terhadap konsentrasi partisipan dalam mengerjakan. Akan tetapi, kendala ini dapat diatasi sebab peneliti langsung melakukan pemeriksaan ulang kuesioner yang telah dikumpulkan oleh partisipan dan menghampiri partisipan yang belum mengisi secara lengkap.

Pengukuran parental career-related behaviors yang digunakan pada penelitian ini tidak menekankan bahwa partisipan harus mengisinya berdasarkan penilaiannya pada pihak yang dianggap lebih berperan dalam perkembangan kariernya (apakah ayah atau ibu) padahal bisa saja porsi peran keduanya berbeda. Hal ini dapat menimbulkan kebingungan bagi partisipan dalam mengisi kuesioner sebab persepsinya terhadap masingmasing pihak akan berbeda. Selain itu, alat ukur komitmen terhadap pilihan karier yang digunakan masih menggunakan bahasa yang tergolong agak sulit dipahami terutama bagi partisipan SMA sehingga beberapa partisipan menanyakan maksud dari kalimat pada alat ukur tersebut. Dengan demikian, berbagai limitasi diatas dapat menjadi pertimbangan dalam penelitian selanjutnya. Hasil penelitian ini memiliki implikasi bagi remaja dan berbagai pihak yang terkait perkembangan karier remaja seperti orang tua dan sekolah. Berikut beberapa saran yang dapat peneliti berikan:

\section{Saran Metodologis}

Untuk meningkatkan kualitas penelitian selanjutnya, maka peneliti memberikan beberapa saran sebagai berikut:

1. Perlu dipertimbangkan pemilihan waktu dalam pemberian kuesioner penelitian. Hendaknya peneliti memilih waktu dimana partisipan mampu berkonsentrasi dengan baik, misalnya di pagi hari, menghindari waktu setelah pelajaran olah raga atau setelah ujian.

2. Penelitian selanjutnya diharapkan dapat memberikan instruksi di awal pengukuran parental career-related behaviors bahwa partisipan mengisi berdasarkan penilaian partisipan pada pihak yang lebih berperan dalam pilihan kariernya (apakah ayah atau ibu).

3. Penggunaan kalimat pada alat ukur komitmen terhadap pilihan karier hendaknya dapat lebih disederhanakan sehingga lebih mudah dipahami terutama bagi partisipan yang masih duduk di bangku sekolah seperti siswa SMA. 


\section{Saran Praktis}

1. Pihak sekolah dapat bekerjasama dengan praktisi pendidikan seperti psikolog atau guru Bimbingan Konseling dalam memberikan psikoedukasi kepada orang tua sehingga membantu siswa dalam mengenali potensi, minat, dan melakukan eksplorasi terhadap berbagai pilihan jurusan kuliah dan karier yang tersedia serta selanjutnya berkomitmen terhadap pilihan yang telah diambil. Akan lebih baik ketika pengenalan terhadap minat, potensi, dan eksplorasi karier dilakukan sejak kelas $X$ sehingga remaja lebih mempersiapkan diri dan lebih mampu meningkatkan kemampuannya dalam menyelesaikan masalah yang muncul selama proses pencapaian tujuan kariernya.

2. Diharapkan orang tua dapat lebih banyak dalam menunjukkan sikap yang memberikan dukungan terhadap perkembangan karier remaja sehingga mereka meyakini kemampuannya dalam mengambil berbagai keputusan karier dan selanjutnya memiliki komitmen yang tinggi terhadap pilihan karier yang telah mereka putuskan.

\section{DAFTAR PUSTAKA}

Bandura, A. (1977). Self efficacy: toward a unifying theory of behavioural change. Psychological Review, 84, 191-215.

Baron, R.M \& Kenny, D.A. (1986). The moderator-mediator variable distinction in social psychological research. Journal of Personality and Social Psychology, 51(6), 1173-1182.

Betz, N.E., \& Luzzo, D.A. (1996). Career assessment and the career decision making self efficacy scale. Journal of Career Assessment, 4(4), 413-428.

Betz, N.E., \& Taylor, K.M. (2006). Evaluation of short form of the career decision making self-efficacy scale. Journal of Career Assessment, 4(1), 47-57.

Blustein, D. (1989). The role of goal instability and career self-efficacy in the career exploration process. Journal of Vocational Behaviors, 35, 194203.

Blustein, D. L., Ellis, M. V., \& Devenis, L. E. (1989). The development and validation of a two-dimensional model of the commitment to career choices process. Journal of Vocational Behaviors, 35, 342-378.

Caldera, Y.M., Robitschek, C., Frame, M., \& Pannell, M. (2003). Intrapersonal, familial, and cultural factors ini the commitment to a career choice of Mexican American and non-Hispanic White college women. Journal of Counseling Psychology, 50(3), 309-323.

Cheng, E.W.L, \& Ho, D.C.K. (2001). The influences of job and career attitudes on learning motivation and transfer. Career Development International. 6(1), 20-28. 
Chung, Y. B. (2002). Career decision-making self-efficacy and career commitment: gender and ethnic differences among college students. Journal of Career Development, 28(4), 277-284.

Demirtas, S.C. (2010). The role of gender, relationship status, romantic relationship satisfaction, and commitment to career choices in the components of subjective well-being among senior university. Turki: Master Dissertation Graduate School of Social Sciences Middle East Technical University.

Dietrich, J. \& Kracke, B. (2009). Career-spesific parental behaviors in adolescents' development. Journal of Vocational Behaviors, 75, 109119.

Ellis, M.V., Wang, N., \& Chen, P. (1999). SES, self-efficacy, and the commitment to career choice process among Trinidad nationals. Boston: American Psychological Association.

Guan, Y., Wang, F., Liu, H., Ji, Y., Jia, X., Fang, Z., Li, Y., Hua., Li, C. (2014). Career-specific parental behaviors, career exploration and career adaptability: A three-wave investigation among Chinese undergraduates. Journal of Vocational Behaviors, 86, 95-103.

Hargrove, B.K., Creagh, M.G., \& Burgess, B.L. (2002). Family interaction patterns as predictors of vocational identity and career decision making self-efficacy. Journal of Vocational Behaviors, 61(2), 185-201.

Hayes, A.F. (2013). Introduction to Mediation, Moderation, and Conditional Process Analysis: A Regression-Based Approach. New York: Guilford Press.

Jin, L., Watkins, D., \& Yuen, M. (2009). Personality, career decision self efficacy and commitment to the career choices process among Chinese graduate students.

Kappler, S. (2015). Picking the wrong college major can be an expensive error. Diakses pada 1 Februari 2018 dari http://www.nbcnews.com/businessmain/picking-the-wrongcollege-major-can-be-an-expensive-error

Ladany, N., Meloncoff, D.S., Constantine, M.G., \& Love, R. (1997). Atrisk urban high school students' commitment to career choice. Journal of Counseling \& Development, 76, 45-52.

Lee, J., \& Kim, M. (2015). Parental attachment, career decision selfefficacy, and commitment to the career choice among Korean college students. Journal of Asia Pasific Counseling, 5(1), 39-52.

Lent, R.W., Brown, S.D, \& Hackett, G. (2000). Contextual supports and barriers to career choice: A social cognitive analysis. Journal of Counseling Psychology, 47, 36-49.

Lopez, F.G. (1994). Further validation of the commitment to career choices scale: extensions to a high school sample. Journal of Career Assessment, 2(4), 398-407. Journal of Vocational Behaviors, 74, 47-52. 
Maulidiyah, A. (2017). Peran parental career-related behaviors terhadap adaptabilitas karier pada mahasiswa tingkat akhir. Skripsi. Depok: Universitas Indonesia.

Nurmi, J. E. (1991). Planning, motivation, and evaluation in orientation of the future: A latent structure analyses. Scadinavian Journal of Psychology, 30, 67-71.

Sawitri, D.R., Creed, P.A., \& Zimmer-Gembeck, M.J. (2012). The adolescent-paren career congruence scale: Development and initial validation. Journal of Career Assessment, 21(2), 210-226.

Sawitri, D.R., Creed, P.A., \& Zimmer-Gembeck, M.J. (2013). Parental influences and adolescent career behaviours in a collectivist cultural setting. International Journal for Educational and Vocational Guidance, 14(2), 161-180.

Scott, D.J. \& Church, T. (2001). Separation/attachment theory and career decidedness and commitment: effect of parental divorce. Journal of Vocational Behaviors, 58, 328-347.

Sharf, R.S. (2010). Applying career development theory to counseling $5^{\text {th }}$ Ed. Unites States of America: Brooks/Cole Cengage Learning.

Taylor, K. M., \& Betz, N. E. (1983). Applications of self-efficacy theory to the understanding and treatment of career indecision. Journal of Vocational Behaviors, 22, 63-81.

Wang, N. (2004). The relations of neuroticism and extraversion to progress in commitment to career choice: a model of mediating mechanisms through career decision making self-efficacy. New York: Dissertation Department of Educational and Counseling Psychology University Albany.

Wang, N., Jome, L.M., Haase, R.F., Bruch, M.A. (2006). The role of personality and career decision-making self efficacy in the career choice commitment of college students. Journal of Career Assessment, 14, 312-332. 
